University of Nebraska - Lincoln

DigitalCommons@University of Nebraska - Lincoln

Faculty Publications, UNL Libraries

Libraries at University of Nebraska-Lincoln

April 2008

Miniature Cattle: For Real, for Pets, for Production

Dana W. R. Boden

University of Nebraska - Lincoln, dboden1@unl.edu

Follow this and additional works at: https://digitalcommons.unl.edu/libraryscience

Part of the Library and Information Science Commons

Boden, Dana W. R., "Miniature Cattle: For Real, for Pets, for Production" (2008). Faculty Publications, UNL Libraries. 146.

https://digitalcommons.unl.edu/libraryscience/146

This Article is brought to you for free and open access by the Libraries at University of Nebraska-Lincoln at DigitalCommons@University of Nebraska - Lincoln. It has been accepted for inclusion in Faculty Publications, UNL Libraries by an authorized administrator of DigitalCommons@University of Nebraska - Lincoln. 


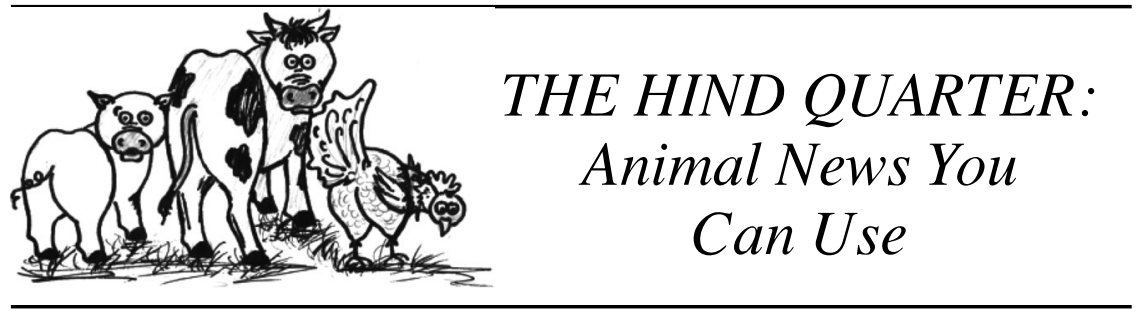

\title{
Miniature Cattle: For Real, For Pets, For Production
}

\author{
Dana W. R. Boden
}

Miniature cattle-the mere mention in conversation has elicited various reactions. Most common have been smiles, chuckles, outright laughter, or the query, "Are you serious?" Upon completely serious assurances that they do exist, the next response tends to be an incredulous, "Really?" That is followed closely by a myriad of questions: When did they get started?; Are they known breeds?; Why would you want miniature cattle?; How

Dana W. R. Boden, Associate Professor/Agricultural Subject Specialist Liaison Librarian, C. Y. Thompson Library, University Libraries, East Campus, University of Nebraska-Lincoln, Lincoln, NE 68583-0717 (E-mail: dboden@unlnotes. unl.edu).

The author would like to thank Richard and Arlene Gradwohl and Ken, Ali and Kristie Petersen for graciously consenting to be interviewed, as well as showing her around their miniature cattle operations.

Artwork by Stephanie Ezzo.

Journal of Agricultural \& Food Information, Vol. 9(2), 2008

Available online at http://jafi.haworthpress.com

(C) 2008 by The Haworth Press. All rights reserved.

doi: 10.1080/10496500802174036 
big/small are they?; Who raises them?; What are they used for?; Where are they raised?; Can you eat/ milk them? Read on for answers.

\section{BIG CATTLE}

Archaeological findings trace modern cattle back about six thousand years, or more, to the two species Bos taurus (humpless cattle) and Bos indicus (humped cattle), which in turn trace back to the progenitor of domestic cattle, the aurochs (Bos primigenius). Part of the process of domestication was often the downsizing of large animals such as cattle, partly due to initial inadequate feeding, but also to serve man's purposes, such as for ease of handling and housing (Cervená 2004). More recent history reveals not only cattle of less bulk in general, but breeds known and prized for their small size. Historically, several breeds of cattle of the British Isles-namely Kerrys, Dexters, and Jerseys (known as Alderney at the time)—were especially prized during the 19th century for their diminutive stature and often chosen to decorate country estates, while being utilized as natural "lawn mowers" (Prentice 1940, 25-27; Sanders 1926, 97-103). Common in northern Europe were cattle which were not only raised for their milk and meat, but also for their use in cultivation. The family cow, or just a small herd, was the norm (Flora 2003, 330-340). In tropical regions of the world there are a handful of breeds of miniature Zebu cattle and the family, or homestead, cow is still common (National Research Council [NRC] 1991, 20).

Cattle in the United States today average nearly 1,300 pounds live weight at slaughter. Just 60 years ago, the average weight had not yet tipped the scales at 900 pounds (U.S. Department of Agriculture [USDA] 1958, 1965 , April 1964-March 2007, 2007). The migration of human populations to cities and higher demand for quality meat after World War II, along with advances in feeding, nutrition, breeding, and production capabilities; drove a change to a "bigger is better" mentality. Producers widely supported this as it meant more money in their pockets after the sale. Beyond the feedlots looking to finish cattle at high weights for high dollar amounts, cattle that were larger and longer of leg were more readily herded across rangelands, with less stress and weight loss. From the dairyman's view, larger cows producing large calves bulked up the milk production volume as well. All of these developments were supported by the development and ready availability of transportation and refrigeration, which made getting the 
product to the consumer in an attractive and flavorful form possible (Ennis 2003, 135-36).

\section{DOWNSIZING}

While the majority of cattle have been being bred to be larger, there has been research and efforts to produce smaller cattle. A rancher in Mexico began breeding for smaller Zebu cattle in the late 1960s. The rancher admitted he began with the idea of creating miniature cattle as house pets for the rich. Later he began working with a veterinary researcher and the focus of the project changed to looking at efficiency and higher production on less land. They received inquiries from many countries, including the U.S. National Research Council (Rohter 1987; NRC 1991, 22-23).

Noticing the cattle in the show ring getting larger, and especially taller, a Texas breeder began a focused program in the 1970s to downsize Hereford cattle which have their foundation in Herefordshire, England in the mid1700s. The Largent family's goal for their Herefords was reduced height, with excellent conformation (Roy R. Largent, n.d.).

In Australia, a research project conducted from 1974 to 1993specifically to determine if larger or smaller Angus cattle were more efficient in converting grass to meat-resulted in the development of the Lowline breed. The Lowlines were the closed herd of smaller cattle in the project. The research showed efficiency was much the same-only 5\% difference. The interest in the cattle at the end of the project assured their survival (Barnett, n.d.).

Meanwhile near Seattle, Washington, Richard and Arlene Gradwohl were seeing the effects of urban sprawl, as housing developments started to sprout up around their property. Arlene, having grown up on a farm, wished to maintain a rural lifestyle. Richard, a community college business professor, investigated the possibilities with an entrepreneurial eye. He soon saw the potential smaller cattle could have on their smaller property. Always stressing new product development, Richard soon was educating himself on miniature and small cattle breeds, acquiring breeding stock, and utilizing linebreeding techniques. Beginning with Dexter cattle and keeping some of their smallest Herefords, his new product focus became developing new breeds of miniature cattle. To date he has developed 18 - yes 18 - new breeds of miniature cattle and is enjoying his working retirement as a Professor Emeritus (Gradwohl interview 2007).

In many regions of the world, especially third world or developing countries, the progression to larger and larger cattle was, and remains, 
impractical. The late 1980s research project of the NRC (1991), which included 80 countries, was done "to raise awareness of the potential of small livestock species" and "geared towards benefiting developing nations." It was noted that smaller breeds were not included in livestock development projects.

\section{SIZE STANDARDS}

The established, recognized size for miniature cattle is somewhat up to interpretation and the guidelines to which you adhere. The International Miniature Cattle Breeders Society and Registry (IMCBSR) - founded and maintained by the Gradwohls since 1989-uses 42 inches at the hip, or hook bone, as the height limit for full miniature cattle, measured at 3 years of age. The weight, dependent on the breed, is from 500 to 700 pounds. Those taller than 42 inches, to 48 inches, are considered mid-size miniatures. The Gradwohls keep the registry for 28 breeds of miniature cattle (IMCBSR website, http://www.minicattle.com/).

The NRC, in its report on what it terms "microcattle," used a mature weight of 300 kilograms (660 pounds) or less, as its guide, with no listed requirements regarding height (NRC 1991 17). The Gradwohls have designated micro-mini-cattle as those less than 36 inches at maturity (Silva 2000, 12-16).

Some breeds list their own specific guidelines, which can be found on each breed's Web site. The Miniature Hereford Breeders Association (http://www.mhbaonline.org/) rules for show cattle state that the height limit for mature bulls is 48 inches, while the maximum for cows is 45 inches. Standards for Dexter cattle call for bulls to measure 38 to 44 inches and weigh no more than 1000 pounds and cows to be 36 to 42 inches, weighing no more than 750 pounds (American Dexter Cattle Association http://www.dextercattle.org/index.htm). Miniature Zebu cattle cannot exceed 42 inches at the withers (behind the hump) at 3 years of age, and cows weigh 300 to 500 pounds, while bulls weigh 400 to 600 pounds (International Miniature Zebu Association http://www.miniaturezebu-cattle.com/).

This all means, of course, that these cattle start out smaller as well. Birth height for a miniature calf brings to mind the length of human babies at birth -19 to 22 inches, though some range up to around 30 inches. However, the work of some breeders, with the goal of even smaller cattle, means some are little more than a foot high at birth. Birth weight can vary widely from breed to breed, too-from around 25 to 65 pounds. 


\section{NOT DWARFS}

Those unfamiliar with cattle may ask if miniature cattle are actually defective. Those knowledgeable of cattle breeding concerns are aware there can be dwarfism in several cattle breeds; including Dexter, Holstein, Angus, Hereford, and Shorthorn. A look at miniature cattle shows they are simply smaller, yet proportioned. In Dexters there is a particular form of dwarfism known as bulldog, which is lethal. Modern research has taken care of this problem. There is now genetic testing for dwarfism, and breed registries often require cattle to be certified free of this gene (Cavanagh et al. 2002, 1-4).

\section{WHY NOW?}

In the United States, recent years have seen several changes in farming. The available land for farms has declined. Small acreages and hobby farms have become quite popular. The 2002 U.S. Census of Agriculture shows that since 1974 the number of small farms, up to 49 acres, has increased by over $46 \%$ (USDA 2002). The changes in farm ownership and uses prompted the USDA Economic Research Service in the late 1990s to develop "Farm Typology Group Definitions." Among the small farm categories are Retirement farms and Residential/lifestyle farms (USDA 2001). The demographics of owners are changing as well. Just from 1997 to 2002 the Census of Agriculture showed that the percentage of women as principal operators of farms in the United States increased by $13.4 \%$ (USDA 2002,1997).

One contributor to the popularity of small-scale farming is tax incentives for landowners that can show agricultural use. In addition, there are many baby boomers looking for what they perceive is a simple agrarian, gentle, farming lifestyle as they head into retirement. Of course, there are also those interested in the environment, conservation, ecology, and/or natural living, contributing to a desire to live closer to the land.

\section{WHY MINIATURE CATTLE?}

Large cattle are not very practical on a small plot of land. Two head of full-size cattle require approximately five acres to maintain, while miniature cattle can be concentrated at around two per acre, dependent of course 
on the available grass and supplemental feeding practices. Cattle are herd animals. Miniatures make it possible to have more than one on a small property.

The breeds most common in the miniature cattle world tend to be more docile than some of the larger breeds. Their small size from birth, as well as the generally smaller numbers in a herd, means owners work with them directly, often training them to be led with a halter from a very early age. Besides the inherited gentleness, their small size makes them easier to handle. Several miniature cattle enthusiasts note that, when one steps on your foot, it's not nearly as bad as with a full-size animal. Also, if a miniature is being uncooperative, giving it a good push is much more likely to yield results. The ease of handling can make miniatures more attractive to women and older retirees (Silva 2000, 12-16). Large cattle can be intimidating - not so with one that you can easily wrap your arm around and have to bend down a bit to do so!

Miniatures also have lower total maintenance costs per head. Regular cattle handling equipment can generally be used, unless your miniatures are extremely small, and the wear and tear on that equipment is less. The costs of confinement and setup for housing are also lower. Fencing does not have to be as tall, representing less financial outlay.

These cattle can be pricey. That means getting started with them can be an investment, but the returns on the investment are good too. Prices can vary widely, but generally are over $\$ 1000$ per head, depending on the availability, or rarity, of the breed, and the heritage behind the breeding stock. Rare breeds with quality traits can be priced in the tens of thousands of dollars (Silva 2000, 12-16). In 1994, Ken and Ali Petersen (Petersen interview 2007) decided to take the plunge and switch from the mixed Angus-Hereford-Charolais cattle operation they had hoped would raise money for their retirement to Miniature Herefords. It took all the income from the sale of 50 cows and 2 bulls to purchase the starter herd of 10 females and a single bull. Thirteen years later they, along with a daughter (Photo 1), are enthusiastic proponents of the breed and fulltime Miniature Hereford ranchers, with about 325 head (Wolfson 2007, 2-3).

\section{VARIED USES}

Miniature cattle can be utilized for the same things as their full-size counterparts, many times for higher income or more efficient results: breeding, beef production, dairy production, and as show cattle. Beyond the "normal" 
PHOTO 1. Kristie Klein, 5'2", daughter of Ken and Ali Petersen, shows the size and approachability of one of the KP Ranch's full-grown miniature Hereford Cows.

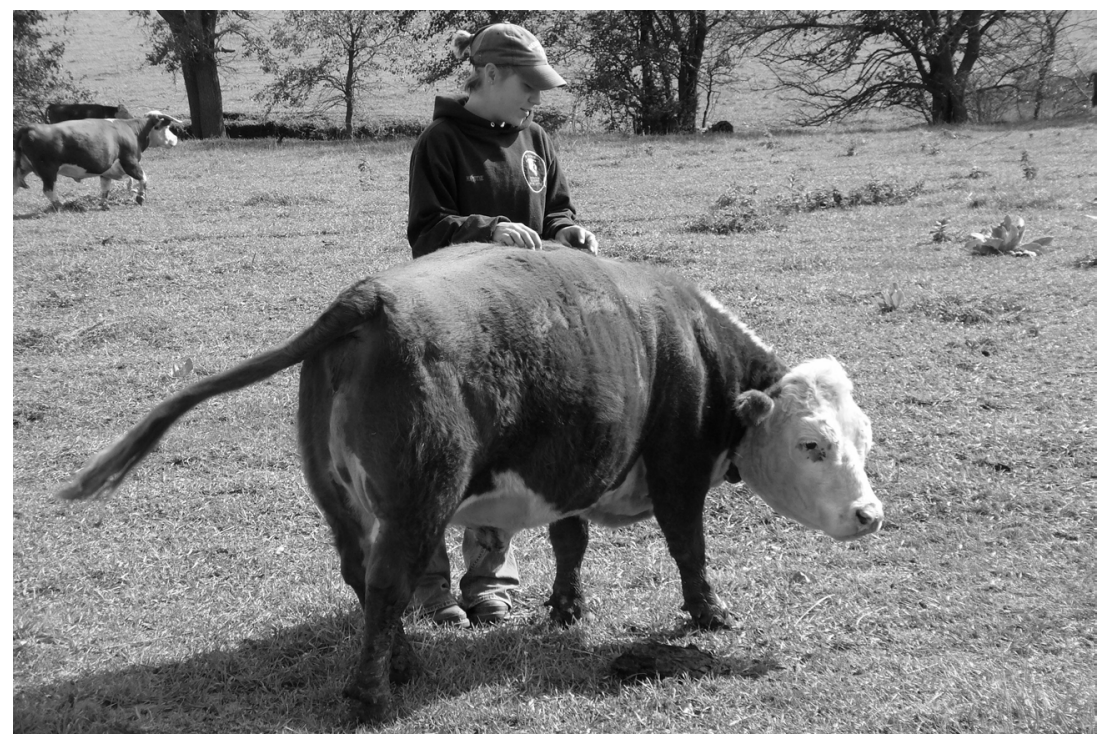

uses, they also may fill a niche market as pets. Another use, due to their size and good nature, is in the agri-tourism industry for petting zoos and educational purposes. And, yes, some miniature bulls are used for youth rodeos!

Using and selling miniature cattle for breeding stock can be a good business. There is not a large population of miniatures, and the demand is rising — some say as much as $20 \%$ per year. Requirements include well-kept records on the heritage of the cattle, documentation of size at birth, ease of calving, and health/immunization records. Sale of semen straws and embryos for implantation can also be an income producer. The Gradwohls, for example, currently have semen priced from $\$ 50$ to $\$ 250$ per straw (dependent on breed) and each embryo at $\$ 1,500$. They also generously donated hundreds of semen straws of their trademarked dual-purpose Kentshire breed for miniature cattle development in South Africa (IMCBSR website http://www.minicattle.com/index.cfm).

Beef production for food is an obvious use. With the popularity today of healthy, hormone-free foods, miniature cattle can easily fill the bill. 
Dependent upon the producer's commitment, feeding capabilities, and meeting standard guidelines, the beef may be marketed as Organic, Natural, or Grass-fed Beef; with the possibility of receiving higher prices for the product. Two of the major miniature breeds are simply smaller versions of the major beef breeds everyone knows-(miniature) Hereford and (Lowline) Angus. Miniature cattle provide a more petite cut of meat, which can be attractive to today's consumer. At the same time, the proportion of the best cuts is larger. The rib eye area in full-size cattle is approximately one square inch per 100 pounds of body weight. In miniatures it is $25 \%-50 \%$ larger-1 $1 / 4$ to $1 \frac{1}{2}$ square inches of rib eye per 100 pounds (Fields 1997, 43). Lowlines have $45 \%$ less back fat than Angus (Goldsberry, n.d.). Many reviews rate miniature beef highly on quality, tenderness, and flavor. It is generally fine-grained with good intramuscular marbling. If your desire is for a family beef, miniatures are excellent. Their small carcass size will not overload your deep freezer, there's no need to figure out who you are going to split the meat with, and it can be eaten by the average family within the recommended freezer life. Miniature beef producers indicate better feed conversion than full size animals, requiring one third to one half the nutrition to finish.

Miniature cattle for dairy production is a developing area. Dexter cattle have been known as a dual-purpose breed (meat and milk) for years, and Jersey cattle were known in earlier decades as a smaller dairy breed. Breeding efforts to get Jersey cattle to official miniature size (what some call Old World Jerseys) have been successful. Miniature Jersey cows will produce approximately two to four gallons of milk per day, at the same high protein and butterfat levels of their full-size counterparts. Again, this could supply a family — and perhaps some relatives, friends, or neighbors—with milk and other dairy products (O'Donnell 2007; M \& B FarView Farm, 2005-2007). The major full-size dairy breed in the United States, the Holstein, is still rare in miniature circles; but under focused development (Gradwohl 2006).

Miniature cattle are a nice, manageable size for young 4-H show participants. Some miniature breeds (Hereford and Lowline) are included in the large, national level livestock shows with considerable prize money up for grabs. If state fairs do not yet include miniature cattle in official competition, producers may simply have them in the barn area, or participate in animal parades, to promote the breeds and pique the public's curiosity. Recently, the Miniature Hereford Breeders Association started a Pre-Junior Show for kids 3 to 10 years of age. This developed due to a producer's children's unending questions of when they would be able to 
show their little steers. The Pre-Junior level debuted at the North American International Livestock Exposition in Louisville, Kentucky in November 2007 and will be at the Houston Livestock Show and Rodeo in March 2008 (Petersen interview 2007).

Then there is the desire by some to have a miniature cow or steer as a pet. While it seems quite a novelty, it does seem to be catching on in some parts of the country. The Gradwohls (Interview) report sales of cattle for pets is currently their biggest market for the cattle they produce on their Happy Mountain Farm. Of course, having a fenced yard, or at least area, is a concern. Some owners like the natural "lawn mower" that comes with owning these miniatures. Even though miniature cattle eat less than their full-size counterparts, they still produce a considerable amount of manure. Suggestions are to use it as natural fertilizer worked into garden soil or spread on pasture (Lewis 2007). Another drawback may be the concern for care if the owner has to be out of town. It may not be as simple as having the neighbor's child come feed and walk the dog.

Miniature cattle also have several potential novelty uses. Some are in farm petting zoos in the growing agri-tourism industry (Sowers 2003). Beyond getting city and urban dwellers up close with cattle of a nonthreatening size, appropriate breeds can also be used for educational purposes regarding the origin of dairy products. At the same time, some working miniature cattle farms feel the need to make a point of stating they are not a petting zoo (M \& B Farview Farm). The Gradwohls (Interview) have had problems with curiosity seekers just showing up at the gate of their farm wanting to come in and see those "cute cattle." In summer 2007 they started offering tours by reservation. In the last few years, Miniature Zebu and Miniature Longhorn cattle have come into use for youth or junior rodeos and for training before transitioning to full-size, professional rodeo bulls (Rotenberger 2006; Sours n.d.). There is now an association for breeders of these miniature cattle (Daniel 2005).

\section{MINIATURE/BOUTIQUE/ACREAGE/MICRO CATTLE?}

While the Gradwohls have defined Full Miniature, Mid-size Miniature, and Micro-mini-cattle, there seems to be no information on just where or when the term "miniature" got chosen to apply to these cattle of smaller stature. They are, after all, simply smaller than the norm; but still animals of good size, conformation and production. Many times in the conversations regarding miniature cattle, it becomes evident that the term brings to mind 
miniature horses, pygmy goats, or pot-bellied pigs. People get images of quite small, basically novelty, cattle from the term.

The NRC's 1991 report used the term "microbreeds" not only for cattle, but also for goats, sheep, and pigs; noting "dwarf" and "miniature" already had "connotations within animal science." The report stated they were "attempting to foster" a "spark of newness and future promise" with the "micro" term (p. 1). The term does not seem to have taken hold. In fact, more recently, the term "minilivestock" has been applied to insects, rodents, frogs and snails which, other than rodents, the NRC research barely mentioned (Paoletti 2005).

The Mexican cattle researcher highlighted in that same NRC report was noted as referring to the Brahman cattle he was downsizing as "bonsai cattle" (p. 22-23). Ralph Sowers (2003) refers to those he breeds as toy cattle, though, according to the Gradwohls' designation, they would be micro-minis. Ian Pullar originally registered his group of Lowline cattle in an organization he called the Australian Boutique Cattle Association (Barnett n.d.).

Some current breeders of what are considered miniature cattle disagree with the miniature term. One Dexter breeder's Web site, regarding the history of the breed, begins with the blatant statement, "Irish Dexters are not miniature cattle." Yet their stature fits the recognized definitions (Chambers 2007). Ken Petersen of KP Ranch commented that it was too bad they got the name Miniature cattle, due to it being misleading. He would have called them something else ... perhaps Acreage cattle (Petersen interview 2007).

\section{BREEDS}

The advantages of each of the various breeds of miniature cattle differ and individual owners will gladly inform you of the reasons they have and prefer the ones they have chosen. Let's take a look at some of the major breeds in the United States.

\section{Dexters}

American Dexter Cattle Association: http://www.dextercattle.org/ index.htm

Purebred Dexter Cattle Association of North America: http://www. purebreddextercattle.org/ 
Dexters are the original small cottage, dual purpose, cattle from Ireland. Having always been smaller than the norm, they have frequently been used in breeding programs to downsize other breeds. They are gentle, fertile, good mothers and good milkers. The Purebred Dexter Cattle Association of North America (PDCA) has over 600 farms/producers in the Breeders List, covering all 50 states and 4 Canadian provinces. Dexters come in three colors: black, dun, and red. Most are horned, though polled Dexters have recently been introduced. Richard Gradwohl currently has White Dexters under development (Gradwohl interview 2007).

\section{Miniature Herefords}

Miniature Hereford Breeders Association: http://www.mhbaonline.org/ Miniature Hereford Club: http://www.miniaturehereford.org/index.html

Miniature Herefords are registered with the American Hereford Association. Their frame scores (Miniatures: 0000-0; Classics: 1-3; Full size: 4-10) identify them as miniatures. Miniature Herefords, like their full-size counterparts, are red with white faces and may be horned or polled. Miniatures were first included in the National Western Stock Show in Denver in 2000. The number of entries has increased each year and includes not only U.S., but also Canadian cattle. Last year the number of Miniature Hereford entries ranked tenth among the nineteen breeds included in the show. They were a part of the North American International Livestock Exposition for the first time at the most recent show in November 2007. It is estimated there are approximately 3,000 head of Miniature Herefords in about 40 states in the U.S. (Petersen interview 2007).

\section{Lowlines}

American Lowline Registry: http://www.usa-lowline.org/

Lowline Cattle are Angus cattle, simply of smaller stature. In the U.S., Herefords and Angus have been, for beef producers, comparable to the "Ford or Chevy" and "John Deere Green or International Harvester Red" preferences of automobile and classic tractor enthusiasts. So, it is no surprise, Lowline Cattle, just introduced to North America from Australia in 1996, have become quite popular. According to the Registry, they are now in all but seven states in the United States. 


\section{Jerseys}

American Miniature Jersey Registry \& Association: http://www. miniaturejerseyassociation.com/index.htm

Jerseys are the most widely dispersed miniature dairy breed in the United States. Beyond their prized milk production, they are very cute, often with deer-like coloring. Their registry includes members in 21 states. The development of miniature Jerseys was no doubt expedited by their former diminutive size and the availability of breeding stock of smaller stature. It will be interesting to watch the work to produce miniature Holsteins and whether their numbers will eventually surpass miniature Jerseys, as they have in the full-size breeds.

\section{Others}

There are several other miniature breeds, perhaps already mentioned, that deserve more comment, despite their lower numbers, due to enthusiastic support from their producers. As stated, Miniature Zebu cattle (International Miniature Zebu Association http://www.miniature-zebucattle.com/) are prized for their disease resistance and heat tolerance. With beauty in the eye of the beholder, their proponents also love the look of the humped cattle. From information available, it seems some of these cattle may be among the smallest bred yet. There are currently members listed in 30 states. There is also a registry for qualifying miniature Shorthorn cattle (American Miniature Shorthorn Registry http://www. miniatureshorthorn.org/registryinfo.htm). Like their full-size counterparts, there are both beef and dairy type shorthorns, and they may be polled or horned.

In the 1920s the Texas Longhorn came closer to extinction than the American Buffalo. An appropriation from Congress helped save them. Their breed association (Texas Longhorn Breeders Association of America http://www.tlbaa.org/) just got its start in 1964 and now includes members in 40 states. Miniature Longhorns are included in the breed registry. Longhorns are noted for their individual uniqueness and range of colors and markings. Miniatures have the same distinctive horns and often may be "square," meaning the tip-to-tip measurement of their horns matches their height (Pillard, n.d.).

Miniature Highlands are long haired, horned beef cattle with a distinctive look. The IMCBSR registers miniature Highlands. However, some 
miniature breeders are also registered with the American Highland Cattle Association (http://highlandcattleusa.org/), so it is difficult to know how widespread the miniatures are. Their look has been compared to that of an Ewok from Star Wars. They are known for their hardiness, thick hides, and for grazing brush, even eating blackberry bushes (Sanders 2005-2007).

Miniature Galloways are beef cattle with a double hair coat, quite popular in Australia (Australian Galloway Association http://www. galloway.asn.au/index.html), but not widespread as purebreds in the United States. The breed guidelines in Australia require less than 50 pounds birth weight and less than 42 inches at 11 months, which, according to frame score charts, would make them mid-size miniatures. They have been used for crossbreeding or in developing new miniature breeds in the United States. They are black, red, dun, and more rarely, white. The miniature belted Galloways are popular for the novelty pattern they may pass on in their genetics. The miniature Galloways do not have their own separate registry in North America. The American Galloway Breeders Association (http://www.americangalloway.com/) is actually based in Canada, but with members listed in 32 U.S. states.

As noted previously, the Gradwohls have focused on developing new breeds of miniature cattle for 35 years. The International Miniature Cattle Breeders Society and Registry (IMCBSR), which they maintain, now keeps records for 28 different breeds. The Registry was started in 1989 and now has just over 7,000 cattle registered worldwide. While they include the major miniature cattle breeds in the registry, those breeds maintain their own separate registries. The extensive IMCBSR Web site has much information regarding their methods for producing a profit with miniature cattle and the various breeds they have registered and trademarked. Only by contacting them directly, however, is it possible to ascertain what breeds went into the development of each of the 18 breeds they have registered or trademarked (Photo 2).

The Gradwohls are not alone in creating new breeds of miniature cattle. Two which address the desire for dual-purpose miniatures are Hersey cattle, developed from crossing Herefords and Jerseys (Falster, 1999-2007), and Jey Low cattle from Jersey and Lowline cattle. The Jey Low carry the Lowline polled trait (Neidhardt 2007, 30-31). Like the cattle on several producers' Web sites, the breed make-up of Sundog toy cattle is not listed (Sowers 2003). Some producers crossbreed for a particular look or to work toward smaller and smaller cattle, usually for the pet market. So the possibilities are only limited by the ingenuity of the breeders, or the requests or suggestions of their growing customer base, and time. 
PHOTO 2. This bull calf is an example of the panda miniature cattle, developed, trademarked, and registered by Richard Gradwohl at Happy Mountain Farm. He will be a sire for the breed and is not for sale, but his excellent markings have brought the Gradwohls some very high dollar offers.

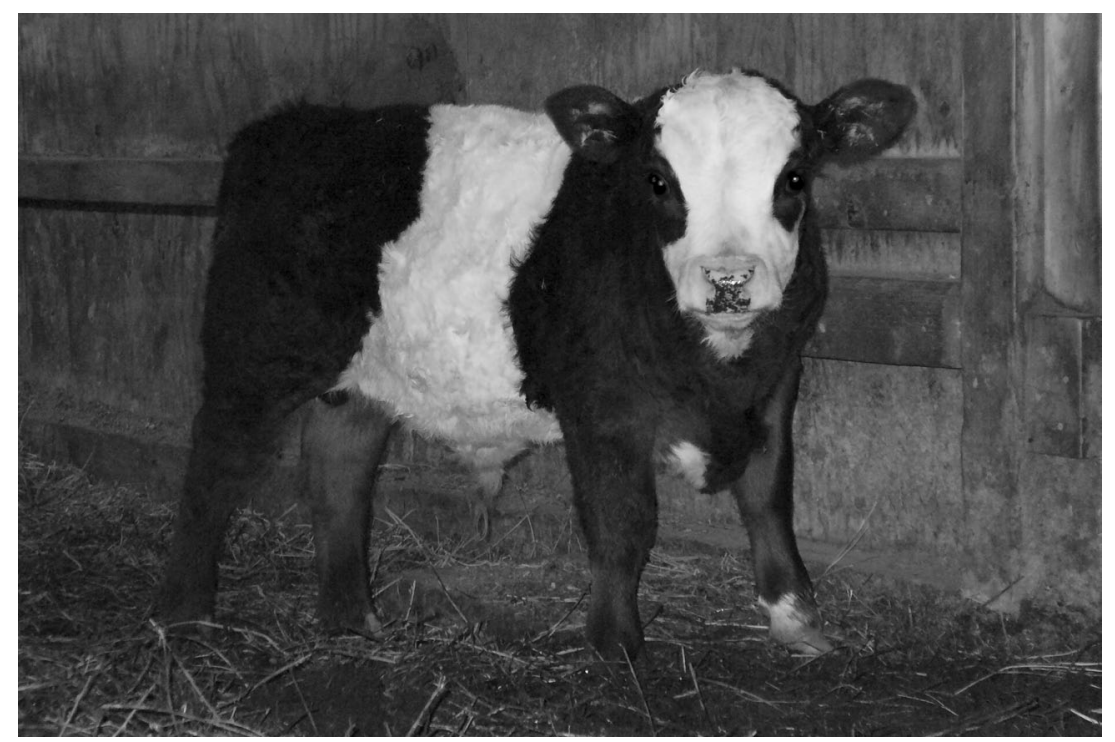

\section{FLYING UNDER THE RADAR}

The NRC report of 1991 included information on twenty-six "representative examples of microcattle," including 17 humpless and 9 humped breeds. Only two breeds included in the report, Florida Scrub (also known as Florida crackers or Pineywoods) (Oklahoma State University 19952007) and Dexters, are listed as in the United States. This is very telling in the history of miniature cattle. At the time of the NRC report, there were so many breeds of these small cattle around the world, yet they had not been researched further or focused on for development in the United States. Miniature cattle have been getting attention in the United States for a relatively short time in the historical perspective.

Whether it's for showing, for the meat, for the milk, for the desired traits for breeding, for a petting zoo, or as simple as having a pet; owners of miniature cattle certainly seem to be an impassioned group of people. It is undeniable that their numbers are growing in the United States. Each Web 
site and each miniature cattle owner contacted is enthusiastic and willing to share information about their animals.

Even Facebook now has three groups devoted to miniature cattle, with a total of 182 members. The largest, with over 100 members, was begun at Kansas State University. Another is mostly northeast U.S.-based and focuses on the trademarked Panda breed developed by Richard Gradwohl. The third was begun at the University of Georgia. Two of the group sites have wall posts. Those vary from very tongue-in-cheek comments, making fun and questioning their existence, to inquiries regarding where they may be found for sale. (Facebook search results accessed December 3, 2007 at http://unl.facebook.com/s.php?q=miniature+cattle\&init=q).

The NRC's 1991 report noted that "small breeds deserve to be studied and developed in their own right." A major reason for its plea was to help third world and developing countries in which so-called "microbreeds" were more practical. There is a wealth of anecdotal evidence expressed on Web sites, in television news video clips, or in short newspaper and magazine articles aimed at small acreage, hobby farmers or at simply highlighting this "cute" novelty to the public. Perhaps with the surge in popularity and rising numbers of miniature cattle in the United States, scholarly, peer-reviewed, documented research will soon be available to support, promote and develop these diminutive bovine breeds to their fullest potential all around the world.

\section{REFERENCES}

Barnett, David. n.d. History of the Lowline breed. American Lowline Registry. http://www.usa-lowline.org/lowline_history.htm (Accessed November 14, 2007).

Cavanagh, J. A. L., I. Tammen, P. A. Windsor, F. W. Nicholas, and H. W. Raadsma. 2002. Identification of the Gene Causing Chondrodysplasia in Dexter Cattle. Paper presented at the Proceedings of the 7th World Congress on Genetics Applied to Livestock Production, August, in Montpellier, France.

Cervená, Alena. 2004. Mammals and humans: Domestication and commensals. In Grzimek's Animal Life Encyclopedia, Edited by Michael Hutchins, Dennis A. Thoney, and Melissa C. McDade. Volume 12: Mammals I. 2nd ed. Detroit: Gale.

Chambers, Jeff. 2007. Silver Maple Dexters. http://www.silvermapledexters.com/index. html, (Accessed November 14, 2007).

Daniel, Shane. 2005. Miniature Bucking Bull Breeders of America. http://www.mbbba.com (Accessed December 1, 2007).

Ennis, Lisa A. 2003. Livestock industry. In Dictionary of American History. Edited by Stanley I. Kutler. Volume 5, 3rd ed. New York: Charles Scribner's Sons. 
Falster, Karl, and Nancy Falster. 1999-2007. Welcome to Falster Farm. http://www. falsterfarm.com/ (Accessed November 29, 2007).

Fields, Nancy. 1997. Miniature Herefords: More profit on less Bovine? AgVentures (August/September) 1 (2): 41-43.

Flora, Cornelia Butler. 2003. Cattle. In Encyclopedia of Food and Culture. Edited by Solomon H. Katz. Volume 1. New York: Charles Scribner's Sons.

Goldsberry, Bill, and Amy Goldsberry. n.d. Lone Tree Lowline Cattle Company, http://www.lonetreelowlinecattle.com/faqs/ (Accessed December 1, 2007).

Gradwohl, Richard H. 2006. The beginners guide: Starting your own miniature cattle business. Covington, WA: International Miniature Cattle Breeders Society.

Gradwohl, Richard H., and Arlene Gradwohl. Personal interview with author, January 22, 2007. Their Web site, International Miniature Cattle Breeders Society and Registry, a division of Cattle Breeders for the Future Corporation, may be accessed at http://www.minicattle.com/entry.cfm.

Lewis, Patrice. 2007. How now house cow: If you're low on space but high on raising cattle, Dexters are the way to go. Grit (July/August). http://www.grit.com/article/2007/07/HowNow-House-Cow.html (Accessed December 3, 2007).

M \& B FarView Farm. 2005-2007. http://www.mbfarviewfarm.com/Miniature-JerseyCows.htm (Accessed December 2, 2007).

National Research Council. Board on Science and Technology for International Development. Panel on Microlivestock. 1991. Microlivestock: Little-known small animals with a promising economic future. Washington, DC: National Academy Press. http:// www.nap.edu/catalog.php?record_id=1831\#toc

Neidhardt, Maureen. 2007. Jey low cattle for a "breed to pure" option. Small Farm Today (May) 24 (3): 30-31.

O’Donnell, Tim. 2007. Welcome to Dexter Corner. http://www.homestead.com/ minijerseysbydexter/index.html (Accessed December 1, 2007).

Oklahoma State University, Department of Animal Science. 1995-2007. Breeds of livestock: Cattle. http://www.ansi.okstate.edu/breeds/cattle (Accessed November 28, 2007).

Paoletti, Maurizio G., editor. 2005. Ecological implications of minilivestock: Potential of insects, rodents, frogs and snails. Lebanon, NH: Science Publishers, Inc.

Petersen, Ken, and Ali Petersen. Personal interview with author, October 12, 2007, http://www.kpranch.com/.

Pillard, Dustin. n.d. Pillard's miniature cattle: Miniature Texas Longhorn cattle, http://www.miniaturebull.com/longhorns.html (Accessed December 1, 2007).

Prentice, E. Parmalee. 1940. The history of Channel Island cattle: Guernseys and Jerseys. Williamstown, MA: Mount Hope Farm.

Rohter, Larry. 1987. Mexican rancher breeds miniature cows. New York Times December 29. http://query.nytimes.com/gst/fullpage.html?res=9B0DE4DE1F31F93AA15751C1A96 1948260 (Accessed November 13, 2007).

Rotenberger, Chad, and Michelle Rotenberger. 2006. Lil' Rowdy Rodeo Bulls. http://www.lilrowdyrodeobulls.com/ (Accessed December 1, 2007).

Roy R. Largent \& Sons Point of Rocks Ranch Miniature Herefords. http://www.miniaturehereford.com/ (Accessed November 27, 2007). 
Sanders, Alvin Howard. 1926. The cattle of the world; their place in the human schemeWild types and modern breeds in many lands. Washington, DC: National Geographic Society.

Sanders, Rick. 2005-2007. Miniature highland cattle. http://www.minihighlandcattle.com/ (Accessed December 3, 2007).

Silva, Beth. 2000. Miniature cattle—For small acreage and more. AgVentures (April/May) 4 (2): 12-16.

Sours, Stan, and Judy Sours. n.d. Welcome to Fern Crest Farm! http://www. ferncrestfarm.com/mini_bulls.htm (Accessed December 1, 2007).

Sowers, Ralph. 2003. Toy cattle. http://www.toycattle.com/ (Accessed November 25, 2007).

U.S. Department of Agriculture. Agricultural Marketing Services. 1958. Table 120-Live weights of livestock slaughtered: Average per head, by class of slaughter, 1921 to 1957. Statistical Bulletin No. 230: Livestock and Meat Statistics 1957. Washington, DC: GPO.

U.S. Department of Agriculture. Consumer and Marketing Service. Statistical Reporting Service. Economic Research Service. 1965. Table 120-Live weights of livestock slaughtered: Average per head, by class of slaughter, 48 state, 1955 to date. Livestock and Meat Statistics. Supplement for 1965 to Statistical Bulletin No. 333. Washington, DC: GPO.

U.S. Department of Agriculture. Economic Research Service. Resource Economics Division. 2001. Structural and Financial Characteristics of U.S. Farms: 2001 Family Farm Report. Agriculture Information Bulletin No. 768. Robert A. Hoppe, editor. http://www. ers.usda.gov/publications/aib768/.

U.S. Department of Agriculture. Economics, Statistics and Market Information System. National Agricultural Statistics Service. 2007. Livestock Slaughter. http://usda.mannlib. cornell.edu/usda/current/LiveSlau/LiveSlau-10-26-2007.pdf.

U.S. Department of Agriculture. Economics, Statistics and Market Information System. National Agricultural Statistics Service. April 1, 1964-March 2, 2007. Livestock Slaughter Annual Summary. http://usda.mannlib.cornell.edu/MannUsda/ viewDocumentInfo.do?documentID $=1097$

U.S. Department of Agriculture. National Agricultural Statistics Service. 2002 Census of Agriculture, Volume 1. Chapter 1: U.S. National Level Data, "Table 1. Historical Highlights: 2002 and Earlier Census Years." http://www.nass.usda.gov/census/ census02/volume1/us/st99_1_001_001.pdf.

U.S. Department of Agriculture. National Agricultural Statistics Service. 2002 Census of Agriculture, Specialty Products and Special Studies. "Minority and Women Principal Operators: 2002 and 1997." http://www.agcensus.usda.gov/Publications/ 2002/FINAL_Counting_Diversity_in_American_Ag.pdf.

Wolfson, Hannah. 2007. Small cattle = large profits: Miniature milkers offer 'a bigger bang for your buck.' Out Here, (Spring): 2-3. 